\title{
INVESTIGATIONS ON NUCLEASE ACTIVITY OF TRANS MIXED LIGAND- COPPER(II) COMPLEXES WITH ORTHO SUBSTITUTED AROMATIC OXIMES AND HETEROCYCLIC BASES
}

\author{
M.S.SURENDRA BABU ${ }^{a}$, PITCHIKA.G.KRISHNA ${ }^{b}$ K.HUSSAIN REDDYY ${ }^{a *}$ AND G.H.PHILIP ${ }^{b}$ \\ ${ }^{a}$ Department of chemistry, Sri Krishnadevaraya university Anantapur-515003, India. \\ ${ }^{b}$ Department of zoology, Sri Krishnadevaraya university Anantapur-515003,India.
}

(Received: September 26, 2008 - Accepted: August 25, 2009)

\begin{abstract}
Mixed ligand complexes of copper(II) with salicyladoxime (SAO), 2-hydroxy acetophenone oxime (HAO) as primary ligands and pyridine( Py), imidazole (Im) as secondary ligands have been synthesized and characterized by molar conductivity, magnetic moments, electronic, IR and ESR spectral data. Cyclic voltammetric studies show quasi-reversible reduction attributable to $\mathrm{Cu}^{2+} / \mathrm{Cu}^{+}$. The binding interactions between metal complexes and calf thymus DNA have been investigated by using UV -Visible titrations and cyclic voltammetry studies. The cleavage activity of complexes was carried out on double-stranded pBR322 circular plasmid DNA by using gel electrophoresis. All complexes show increased nuclease activity in the presence of oxidant $\left(\mathrm{H}_{2} \mathrm{O}_{2}\right)$. The nuclease activity of mixed ligand complexes are compared with that of the parent copper(II) complexes. Controlled experiments suggest that the complexes cleave DNA predominantly via an oxidative mechanism.
\end{abstract}

Keywords: Copper(II) complexes; mixed ligand complexes, aromatic oximes, DNA binding, oxidative cleavage.

\section{INTRODUCTION}

Investigations on transition metal complexes to probe nucleic acids are becoming more prominent in the research area of bioinorganic chemistry ${ }^{1 " 7}$. Copper complexes are well established as chemical nucleases and known to cleave DNA by different mechanisms viz. hydrolytic ${ }^{8}$ and oxidative $e^{9,10}$. Oxidative cleavage of DNA could take place by chemical or photochemical means. Chemists are in search of new transition metal complexes as chemical nuclease. Oximes are widely recognized ligands in different fields of chemistry ${ }^{11} 14$. Survey of literature revealed that metal complexes of such important ligands are not exploited much in DNA studies. Transition metal complexes of ortho substituted aromatic oximes have attracted much attention as they give cis and trans geometrical isomers. Copper complexes are known to assume trans structure while cobalt complexes have cis- structure. Investigations of DNA interactions and cleavage activity of metal complexes with oximes are very limited.

In the light of above and in continuation of our on-going ${ }^{15,16}$ research work on DNA interactions with metal complexes, herein we describe synthesis, characterization, DNA cleavage / binding studies on mixed ligand complexes with salicylaldoxime(SAO), 2- hydroxyacetophenone oxime (HAO) as primary ligands and pyridine (Py) and imidazole ( $\mathrm{Im}$ ) as secondary ligands.

\section{EXPERIMENTAL}

\section{Materials and Methods}

All the reagents used in the preparation of ligands and their metal complexes were of reagent grade (Merck). The solvents used in the synthesis of ligands and metal complexes were distilled before use. All other chemicals were of AR grade and used without further purification. pBR322 DNA and Calf thymus DNA were purchased from Bangalore Genie(India). Agarose, Tris. $\mathrm{HCl}$ and ethidium bromide were procured from Sigma-Aldrich. All other chemicals were of Merck make.

The elemental analyses were performed using Perkin Elmer 2400 CHNS elemental analyzer. Magnetic moments were determined in the polycrystalline state on a PAR model 155 vibrating sample magnetometer operating at field strength of 2-8 kG. High purity Ni metal (Saturation moment 55e.m.u/g) was used as standard. The molar conductance of the complexes in DMF $\left(10^{-3}\right.$ M) solution was measured at $28 \pm 2^{\circ} \mathrm{C}$ with a Systronic model 303 directreading conductivity bridge. The electronic spectra were recorded in DMF with a Schimadzu UV-160A spectrophotometer. The FAB-mass spectra were recorded at Indian Institute of chemical Technology, Hyderabad on Joel SX 102/DA-6000 mass spectrometer using m-nitrobenzylalcohol as the matrix. FT-IR spectra were recorded in the range $4000-50 \mathrm{~cm}^{-1}$ with a Bruker IFS $66 \mathrm{~V}$ in $\mathrm{KBr}$ and polyethylene medium. ESR spectra were recorded on Varian E-122 X-band spectrophotometers at liquid nitrogen temperature in DMF. The voltammetric measurements were performed on Bio-Analytical systems, (BAS) CV-27 assembly in conjunction with an X-Y recorder. Measurements were made on the degassed $\left(\mathrm{N}_{2}\right.$ bubbling for $\left.5 \mathrm{~min}\right)$ solution in DMF $\left(10^{-3} \mathrm{M}\right)$ containing $0.1 \mathrm{M}$-tetraethylammonium perchlorate $\left(\mathrm{Et}_{4} \mathrm{NClO}_{4}\right)$ as the supporting electrolyte. Three-electrode system consisted of a glassy carbon (working) platinum (auxiliary) and $\mathrm{Ag} / \mathrm{AgCl}$ (reference) electrode.

\section{Preparation of ligands}

The ligands $\mathrm{SAO}$ and $\mathrm{HAO}$ were prepared by the reaction of hydroxylammoniumchloride $\left(\mathrm{NH}_{2} \mathrm{OH} . \mathrm{HCl}\right)$ with salicylaldehyde or 2-hydroxyactophenone.Hydroxylammoniumchloride $(6.5 \mathrm{~g}, 0.1 \mathrm{~mol})$ and salicylaldehyde $\left(13 \mathrm{ml}, 0.1 \mathrm{~mol}, \mathrm{~d}=1.146 \mathrm{~g} / \mathrm{cm}^{3}\right)$ or 2-hydroxyacetophenone $\left(15 \mathrm{ml}, 0.1 \mathrm{~mol}, \mathrm{~d}=1.131 \mathrm{~g} / \mathrm{cm}^{3}\right)$ were taken in $50 \%$ aqueous methanol. The resulting mixture was acidified with few drops of glacial acetic acid and refluxed for $2 \mathrm{hrs}$. The precipitated compound was filtered, washed with cold water, dried under vacuum and recrystallized from aqueous ethanol. SAO: Yield: 87\%, MS: $(\mathrm{m} / \mathrm{z})-137\left(\mathrm{M}^{+}\right), 119\left(\mathrm{M}^{+}-\mathrm{H}_{2} \mathrm{O}\right) ; 93\left(\mathrm{C}_{6} \mathrm{H}_{5} \mathrm{O}^{+}\right) ; 65\left(\mathrm{C}_{5} \mathrm{H}_{5}{ }^{+}\right) ; 39\left(\mathrm{C}_{3} \mathrm{H}_{3}^{+}\right)$. ${ }^{1} \mathrm{H}-\mathrm{NMR}\left(\mathrm{CDCl}_{3}\right) \delta: 9.91(\mathrm{~s}) 1 \mathrm{H}, \mathrm{Oxime}-\mathrm{OH} ; 8.26(\mathrm{~s}) 1 \mathrm{H}$, iminic proton;7.73(s) $1 \mathrm{H}$ phenolic-OH; $6.82-7.14(\mathrm{~m}) 4 \mathrm{H}$ aromatic. HAO : Yield $92 \%$, MS: $(\mathrm{m} / \mathrm{z})-$ 151 $\left(\mathrm{M}^{+}\right), 134\left(\mathrm{M}^{+}-\mathrm{OH}\right) ; 105\left(\mathrm{C}_{6} \mathrm{H}_{5} \mathrm{~N}^{+} \mathrm{CH}_{3}\right) ; 93\left(\mathrm{C}_{6} \mathrm{H}_{5} \mathrm{O}^{+}\right), 65\left(\mathrm{C}_{5} \mathrm{H}_{5}^{+}\right) ; 39\left(\mathrm{C}_{3} \mathrm{H}_{3}^{+}\right)$. ${ }^{1} \mathrm{H}-\mathrm{NMR}\left(\mathrm{CDCl}_{3}\right) \delta$ : $11.5(\mathrm{~s}) 1 \mathrm{H}$ Oxime-OH; 8.2 (s) phenolic-OH; 6.8-7.4 (m) $4 \mathrm{H}$, aromatic; 2.4 (s) $3 \mathrm{H}$, methyl protons.

\section{Copper oximes complexes}

Complexes were prepared by mixing copper(II) chloride $(4.3 \mathrm{~g}, 0.025 \mathrm{~mol})$ and oxime [SAO $(6.9 \mathrm{~g}, 0.05 \mathrm{~mol})$ or $\mathrm{HAO}(7.5 \mathrm{~g}, 0.05 \mathrm{~mol})]$ in $1: 2$ ratio in $50 \%$ aqueous ethanolic medium. The reaction mixture was stirred for $30 \mathrm{~min}$. The green precipitate formed was filtered, washed with hot water and then with cold methanol. The complexes were dried at $110^{\circ} \mathrm{C} . \mathrm{Cu}(\mathrm{SAO})_{2}$ : Yeild $=85 \%$, M.P. $=208-210^{\circ} \mathrm{C}, \mathrm{C}=50.32(50.27), \mathrm{H}=3.38(3.5), \mathrm{N}=8.19(8.32) . \mathrm{Cu}(\mathrm{HAO})_{2}$ : Yeild $=98 \%$, M.P. $=234-237^{\circ} \mathrm{C}, \mathrm{C}=51.67(52.59) \mathrm{H}=4.89(4.92), \mathrm{N}=7.62(7.66)$.

Mixed ligand complexes with pyridine.

Copper(II) complex $(0.005 \mathrm{~mol})$ of SAO or HAO was placed in a Schlenk tube and dissolved in pyridine $\left(3 \mathrm{ml}, 0.981 \mathrm{~g} / \mathrm{cm}^{3}\right)$. The solution was stirred magnetically for $30 \mathrm{~min}$ and $\mathrm{n}$-hexane $(25 \mathrm{ml})$ was added. After standing for 3-4 days, the resulting dark green product formed was washed with water and $\mathrm{n}$-hexane and then dried under reduced pressure over $\mathrm{CaCl}_{2}$. $\mathrm{Cu}(\mathrm{SAO})_{2} \mathrm{Py}_{2}:$ Yeild $=60 \%$, M.P. $=180-184^{\circ} \mathrm{C}, \mathrm{C}=57.75(58.32), \mathrm{H}^{2}$ $3.81(4.42), \mathrm{N}=11.44(11.39) . \mathrm{Cu}(\mathrm{HAO})_{2} \mathrm{Py}_{2}:$ Yeild $=54 \%$, M.P. $=225-227^{\circ} \mathrm{C}$, $\mathrm{C}=56.56(56.60) \mathrm{H}=4.91(5.16), \mathrm{N}=9.41(9.44)$.

\section{Mixed ligand complexes with imidazole}

The copper(II) complex $(1.8 \mathrm{gm}, 0.01 \mathrm{~mol})$ was placed in a $250-\mathrm{ml}$ round bottom flask. Imidazole $(1.5 \mathrm{gm}, 0.05 \mathrm{~mol})$ dissolved in $\mathrm{CH}_{2} \mathrm{Cl}_{2}$ was added to the contents of the flask. The reaction mixture was refluxed on water bath for $2 \mathrm{hrs}$. A dark green precipitate was formed. It was filtered, washed with cold hexane and dried under vacuo over $\mathrm{CaCl}_{2} . \mathrm{Cu}(\mathrm{SAO})_{2} \mathrm{Im}_{2}$ : Yeild $=58 \%$, M.P. $=185-188^{\circ} \mathrm{C}, \mathrm{C}=47.35(47.44), \mathrm{H}=3.78(3.74), \mathrm{N}=19.54(19.58) . \mathrm{Cu}(\mathrm{HAO})_{2} \mathrm{Im}_{2}$ 
: Yeild $=48 \%, \quad$ M.P. $=225-227^{\circ} \mathrm{C}, \mathrm{C}=52.31(52.52), \mathrm{H}=4.72(4.94), \mathrm{N}=$ 12.42(12.65).

\section{DNA -binding studies}

Solution of CT DNA in $0.5 \mathrm{mM} \mathrm{NaCl} / 5 \mathrm{mM}$ Tris- $\mathrm{HCl}(\mathrm{pH}=7.0)$ gave a ratio of UV absorbance at 260 and $280 \mathrm{~nm}, \mathrm{~A}_{260} / \mathrm{A}_{280}$ of 1.8-1.9, indicating DNA was sufficiently free of protein. Concentrated stock solution of DNA was prepared in $5 \mathrm{mM}$ Tris- $\mathrm{HCl} / 50 \mathrm{mM} \mathrm{NaCl}$ in water, $\mathrm{pH}=7.0$ and the concentration of CT DNA (in nucleotide phosphate, NP) were determined by UV absorbance at $260 \mathrm{~nm}$ after 1:100 dilutions. The molar absorption coefficient was taken as $6600 \mathrm{M}^{-117}$.

Solutions for titrations were prepared with the appropriate copper complexes $(35 \mu \mathrm{M}$ of a $2.0 \mathrm{mM}$ solution in DMF), calf-thymus DNA (225 $\mu \mathrm{M}$ in $\mathrm{NP}$ ), $\mathrm{NaCl}$ (final concentration $50 \mathrm{mM}$ ) and Tris- $\mathrm{HCl}$ buffer $(\mathrm{pH}=7.0$, final concentration $50 \mathrm{mM}$ ) and diluted with $\mathrm{H}_{2} \mathrm{O}$ to a total volume of $1 \mathrm{~mL}$. After equilibration (ca.10 min), spectra were recorded against an analogous blank solution containing the same concentration of CT DNA and Tris- $\mathrm{HCl}$ / $\mathrm{NaCl}$ buffer. $\mathrm{K}_{\mathrm{b}}{ }^{18}$

The data were then fitted to eq (1) to obtain the intrinsic binding constant,

$[D N A] /\left(\varepsilon_{\mathrm{a}}-\varepsilon_{\mathrm{f}}\right)=[\mathrm{DNA}] /\left(\varepsilon_{\mathrm{b}}-\varepsilon_{\mathrm{f}}\right)+1 / \mathrm{K}_{\mathrm{b}}\left(\varepsilon_{\mathrm{b}}-\varepsilon_{\mathrm{f}}\right)$

Where $\varepsilon_{\mathrm{a}}, \varepsilon_{\mathrm{f}}$ and $\varepsilon_{\mathrm{b}}$ are apparent, free and bound metal complex extinction coefficients respectively. A plot of [DNA]/ $\left(\varepsilon-\varepsilon_{f}\right)$ Vs [DNA] gave a slope of $1 /\left(\varepsilon_{b}-\varepsilon_{f}\right)$ and a Y-intercept equal to $1 / K_{b}\left(\varepsilon_{b}-\varepsilon_{f}\right), K_{b}$ is the ratio of the slope to the Y-intercept.

\section{Assay of DNA Cleavage activity.}

The DMF solution containing metal complexes was taken in a clean Eppendroff tube and $1 \mu \mathrm{l}$ of plasmid DNA was added. The contents were incubated for $2 \mathrm{hr}$ at $37{ }^{\circ} \mathrm{C}$ and loaded on $0.8 \%$ agarose gel after mixing $5 \mu \mathrm{l}$ of loading buffer $(0.25 \%$ bromophenol blue $+25 \%$ xylene cyanol $+30 \%$ glycerol $)$. Electrophoresis was performed at constant voltage $(80 \mathrm{~V})$ till the bromophenol blue reaches to $3 / 4$ of the gel. Further the gel is stained for $10 \mathrm{~min}$ by immersing it in ethidium bromide solution $\left(5 \mu \mathrm{g} / \mathrm{ml}\right.$ of $\left.\mathrm{H}_{2} \mathrm{O}\right)$. The gel was then de-stained for $10 \mathrm{~min}$ by keeping it in sterile distilled water and plasmid band were visualized by viewing the gel under transilluminator and photographed. The efficiency of the DNA cleavage was measured by determining the ability of the complex to form open circular (OC) or nicked circular (NC) DNA from its supercoiled (SC) form by quantitatively estimating the intensities of the bands using the Vilber Lourmat(V 99.01) Gel Documentation System. The reactions were carried out in presence and absence of $\mathrm{H}_{2} \mathrm{O}_{2}$. Control experiments were done in presence of DMSO, glycerol and tert. butyl alcohol as free radical scavenger.

\section{Results and discussions}

The present ligands contained two functional groups viz., oxime and phenolic (-OH) groups (Fig.1). All complexes are stable at room temperature, non hygroscopic, insoluble in water, but partially soluble in methanol, ethanol and completely soluble in dimethylformamide (DMF). The molar conductance and magnetic moment data are summarized in table 1. Analytical data support the formulae of complexes. The molar conductivity data suggest that the complexes are non-electrolytes. The magnetic moment data indicate that the complexes are monomers.

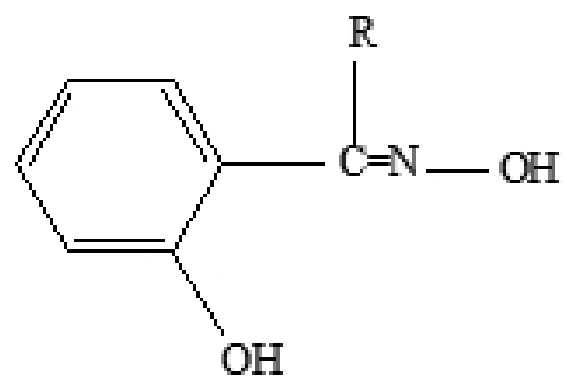

Table 1- Molar conductivity and Magnetic susceptibility of Copper Complexes

\begin{tabular}{|c|l|c|c|}
\hline S.No & \multicolumn{1}{|c|}{ Complexes } & $\begin{array}{c}\text { Molar conductance } \\
\left(\mathrm{ohm}^{-1} \mathrm{~cm}^{2} \mathrm{~mol}^{-1}\right)\end{array}$ & $\begin{array}{c}\mu_{\text {eff }} \\
(\mathrm{B} . \mathrm{M})\end{array}$ \\
\hline I & $\mathrm{Cu}(\mathrm{SAO})_{2}$ & 5.8 & 2.18 \\
\hline II & $\mathrm{Cu}(\mathrm{SAO})_{2}(\mathrm{Py})_{2}$ & 12.0 & 2.48 \\
\hline III & $\mathrm{Cu}(\mathrm{SAO})_{2}(\mathrm{Im})_{2}$ & 14.5 & 2.42 \\
\hline IV & $\mathrm{Cu}(\mathrm{HAO})_{2}$ & 7.0 & 1.83 \\
\hline V & $\mathrm{Cu}(\mathrm{HAO})_{2}(\mathrm{Py})_{2}$ & 12.6 & 2.58 \\
\hline VI & $\mathrm{Cu}(\mathrm{HAO})_{2}(\mathrm{Im})_{2}$ & 12.9 & 2.42 \\
\hline
\end{tabular}

The electronic spectral data of metal complexes recorded in DMF are given in table 2. A single d-d band is observed in the electronic spectra of complexes in $14900-17200 \mathrm{~cm}^{-1}$ region. This band is assigned to ${ }^{2} \mathrm{E}_{\mathrm{g}} \rightarrow{ }^{2} \mathrm{~T}_{2 \mathrm{~g}}$ transition, in favor of octahedral structure facilitated by coordination of DMF solvent molecules in axial position. Due to increase in the ligand field strength a blue shift is observed in the $\mathrm{d}-\mathrm{d}$ band of mixed ligand complexes. ${ }^{19}$

Table 2 - Electronic spectral data (cm-1) of copper (II) complexes in DMF solvent.

\begin{tabular}{|c|c|c|c|}
\hline Complexes & $\begin{array}{c}\text { Charge transfer } \\
\text { (CT) }\end{array}$ & $\pi-\pi^{*}$ & $\mathrm{~d}-\mathrm{d}$ \\
\hline I & 35710 & 28570 & 14950 \\
\hline II & 35710 & 28560 & 15150 \\
\hline III & 35070 & 28560 & 15380 \\
\hline IV & 36360 & 29762 & 15625 \\
\hline V & 38410 & 29760 & 17180 \\
\hline VI & 38460 & 28570 & 16660 \\
\hline
\end{tabular}

\section{Mass spectra}

The FAB mass spectra of parent complexes and mixed complexes are used to compare the stoichiometric composition. The molecular ion peak $\mathrm{M}+$ for parent complexes were observed at $\mathrm{m} / \mathrm{z}=334$ and 362 , suggesting the stoichiometry of parent complexes as $\mathrm{ML}_{2}$. The molecular ion peak of mixed ligand complexes were observed at $\mathrm{m} / \mathrm{z}=413$ and 441 for pyridine adducts and 402 and 430 for imidazole adducts respectively. The stoichiometry of the mixed ligand complexes as $\mathrm{ML}_{2} \mathrm{~L}_{2}$.

Elemental analysis values are in close agreement with the values calculate from molecular formula assigned to these complexes, which is further supported by the FAB-mass studies of representative complexes.

\section{I.R spectra}

The important IR spectral bands of ligands / complexes and their assignments are given in table 3 . Strong bands observed at $3300,3350 \mathrm{~cm}^{-1}$ in the IR spectra of SAO and $\mathrm{HAO}$ respectively are assigned to $v \mathrm{OH}$ vibration of phenolic group ${ }^{20}$. The low $\mathrm{vOH}$ values are possibly due to intramolecular hydrogen bonding as shown below.

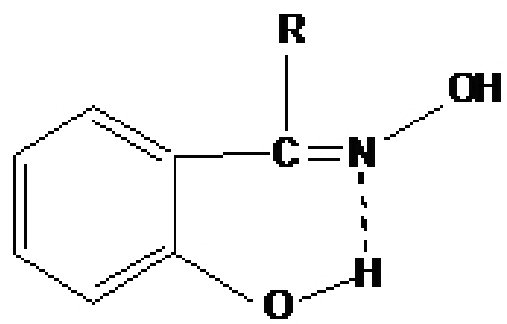

Figure1: Structure of ligands. 
This strong band is absent in copper chelates suggesting the deprotonation of phenolic group and formation of covalent bond between phenolic oxygen and metal. Strong band observed at $1618,1634 \mathrm{~cm}^{-1}$ in the IR spectra of SAO and HAO respectively are assigned to $>\mathrm{C}=\mathrm{N}$ - stretching vibration. This band is shifted to lower frequency in complexes revealing the participation of azomethine nitrogen in chelation. The non-ligand bands observed in the far IR spectra of metal complexes are assigned (table 3) to vM-N, M-O stretching vibrations. Additional bands observed (1610-1600, 1540-1520, 260-220, 245-230 $\left.\mathrm{cm}^{-1}\right)$ in the IR spectra of mixed ligand complexes are presumably due to the binding of bases (pyridine/ imidazole) to copper via nitrogen donor atoms preferably in axial positions ${ }^{21}$.

Table 3. Selected I.R. bonds $\left(\mathrm{cm}^{-1}\right)$ with tentative assignment

\begin{tabular}{|c|c|c|c|c|c|c|c|}
\hline Complex/Ligand & Oxime-OH & $v \mathrm{C}=\mathrm{N}$ & $\begin{array}{c}v C=N \\
\mathrm{Py} / \mathrm{im}\end{array}$ & vAr-H & $v M-N$ & $\begin{array}{c}\text { vM-N } \\
\text { Py / Im }\end{array}$ & vM-O \\
\hline I & 3168 & 1585 & -- & $1590-1340$ & 470 & -- & 570 \\
\hline II & 3162 & 1568 & 1556 & $1580-1350$ & 474 & 263 & 592 \\
\hline $\mathrm{HAO}$ & 3210 & 1634 & -- & $1600-1420$ & -- & -- & -- \\
\hline IV & 3145 & 1624 & -- & $1600-1350$ & 472 & -- & 575 \\
\hline $\mathbf{V}$ & 3162 & 1620 & 1560 & $1500-1350$ & 472 & 255 & 520 \\
\hline
\end{tabular}

In the IR spectra of SAO and HAO bands observed respectively at 3260 and $3210 \mathrm{~cm}^{-1}$ are assigned to oxime $\mathrm{OH}$ stretching vibrations. These bands are respectively observed at 3200 to $3150 \mathrm{~cm}^{-1}$ in the chelates, indicating the involvement of oxime $\mathrm{OH}$ in strong hydrogen bonding leading to the formation of stable 5-membred ring structure. From above observation it is concluded that oxime $-\mathrm{OH}$ is neither deprotonated nor participated in chelation. Observance of three evenly distributed bands in $620-450 \mathrm{~cm}^{-1}$ region is the characteristic of trans-structure for the complexes ${ }^{22}$. IR spectral data together with electronic and magnetic moment data suggest the trans square planar structure for cuproxime and trans octahedral structure for mixed ligand copper(II) complexes (Figure 2a-b).

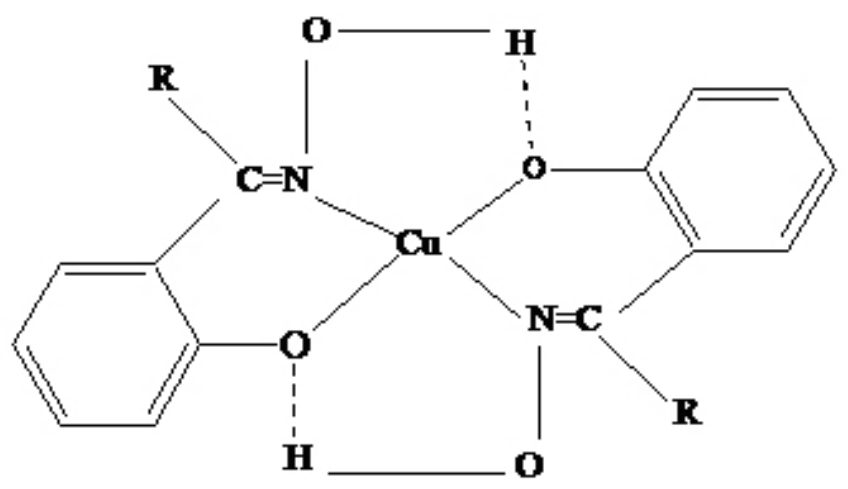

Figure 2a. Structure of copper (II)-Oxime (parent) complexes

Where $\begin{array}{ll}\mathrm{R}=\mathrm{H} & \mathrm{SAO} \\ \mathrm{R}=\mathrm{CH}_{3} & \mathrm{HAO}\end{array}$

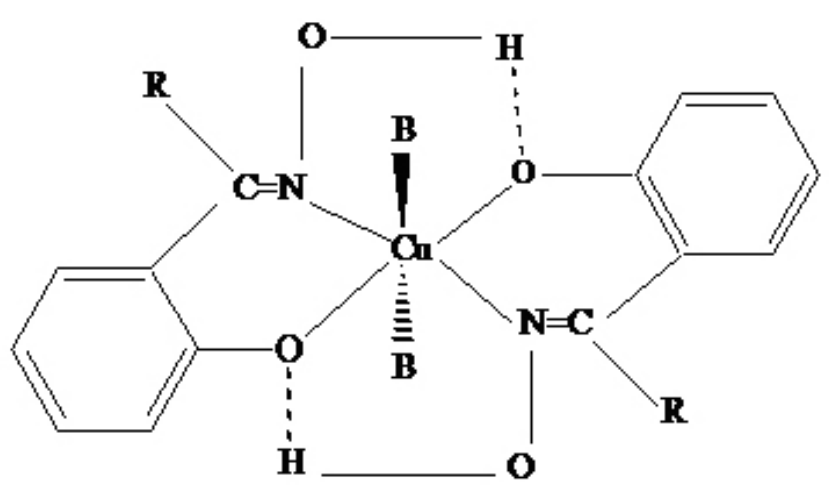

Figure 2b. Structure of mixed ligand copper (II) complexes

Where $\quad \mathrm{R}=\mathrm{H} \quad \mathrm{HAO}$
$\mathrm{R}=\mathrm{CH}_{3}$

$\mathrm{B}=$ Pyridine $/$ Imidazole

ESR spectra of all complexes were recorded in DMF at liquid nitrogen temperature. The ESR spectra of mixed ligand complexes exhibit a set of four well-resolved peaks in the low field region and single signal in high field region; corresponding to $g_{\|}$and $g_{\perp}$ respectively. A typical spectrum of $\left[\mathrm{Cu}(\mathrm{HAO})_{2} \mathrm{Im}_{2}\right]$ shown in Figure 3. The spin Hamiltonian, orbital reduction and bonding parameters of these complexes are given in Table 4. The shape of ESR spectra indicates the geomentry around the copper(II) is not trigonal bipyramidal for the present complexes since the low field side of the ESR spectrum is less intense than the high field side. The g-tensor value of the copper complex can be used to derive the ground state. The trend $g_{\|}>g_{1}>2.0023$ observed for the present copper is typical of a copper(II) $\left(\mathrm{d}^{9}\right)$ ion in axial symmetry with unpaired electron present in the $d_{x}^{2}{ }^{2}$ orbital. The ESR spectra of the copper complex indicates a resolved hyperfine structure in the perpendicular region due to the interaction of the $\mathrm{Cu}(\mathrm{II})$ odd electron with nitrogen atoms. The magnetic susceptibility value reveals that the copper complexes corresponding to the one unpaired electron, indicating that the complex is mononuclear. This fact was also evident from the absence of a half field signal, observed in the spectrum at $1600 \mathrm{G}$ due to the $\mathrm{ms}= \pm 2$ transitions, ruling out any $\mathrm{Cu}-\mathrm{Cu}$ interaction ${ }^{23}$. If the $\mathrm{G}<4$, the ligand forming copper(II) complex is regarded as a strong field ligand. From the observed value the ligand is strong field and metal-ligand bonding in the copper complex is covalent. Hathaway etal suggest $\mathrm{K}_{\|}<\mathrm{K}_{\perp}$, for in-plane $\pi$ - bonding, while $\mathrm{K}_{\perp}<\mathrm{K}_{\|}$for out-of-plane $\pi$ - bonding. 
The observed $\mathrm{K}_{\|}<\mathrm{K}_{\perp}$ relation indicates the presence of in-plane $\pi$-bonding ${ }^{24}$. The axial symmetry parameter $(\mathrm{G})$ for these complexes indicates that there is no interaction between copper centers in DMF medium. Massacesi ${ }^{25}$ reported $\mathrm{g}_{\|}$values in the range 2.2 to 2.4 for complexes containing nitrogen and oxygen donor atoms. The present complexes have $\mathrm{g}_{\|}=2.2-2.4$ in conformity with both $\mathrm{Cu}-\mathrm{O}$ and $\mathrm{Cu}-\mathrm{N}$ bonds.

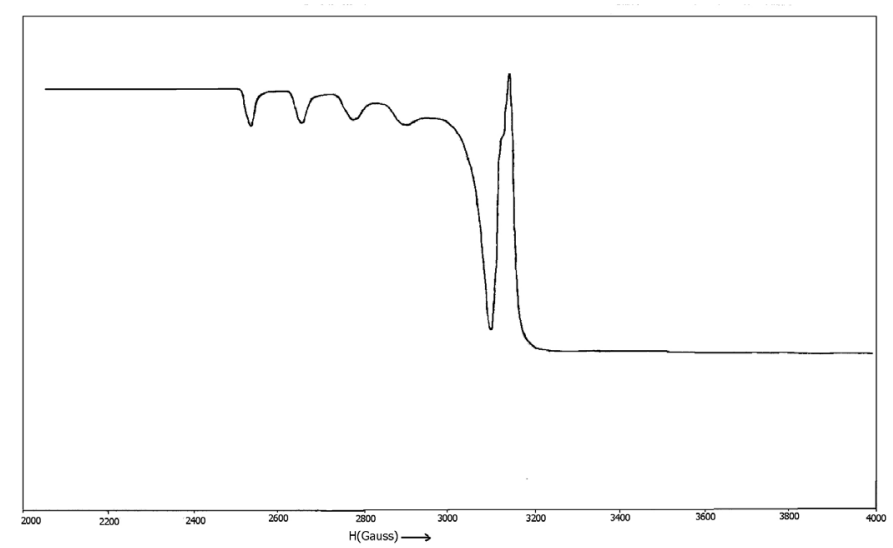

Figure 3. X-band ESR spectra of IV at liquid nitrogen temperature

Table 4. ESR data of copper (II) complexes at liquid nitrogen temperature

\begin{tabular}{|c|c|c|c|c|c|c|}
\hline Complex & $\mathrm{g}$ & $\mathrm{g}_{\perp}$ & $\mathrm{g}_{\text {avg }}$ & $\mathrm{G}$ & $\mathrm{K}_{\sqcup}$ & $\mathrm{K}_{\perp}$ \\
\hline $\mathrm{I}$ & 2.203 & 2.032 & 2.089 & 6.757 & 0.512 & 0.542 \\
\hline II & 2.211 & 2.038 & 2.062 & 5.762 & 0.513 & 0.587 \\
\hline III & 2.221 & 2.031 & 2.058 & 3.787 & 0.513 & 0.526 \\
\hline IV & 2.374 & 2.044 & 2.087 & 4.118 & 0.639 & 0.645 \\
\hline V & 2.301 & 2.057 & 2.172 & 7.279 & 0.681 & 0.727 \\
\hline VI & 2.347 & 2.051 & 2.149 & 7.078 & 0.7124 & 0.885 \\
\hline
\end{tabular}

Electro chemical data of complexes obtained at glassy carbon electrode in DMF are given in table 5. The cathodic peak current function values were found to be independent of the scan rate. Repeated scans as well as different scan rates showed that dissociation does not take place. Figure 4 shows the profile of $\mathrm{Cu}(\mathrm{HAO})_{2} \mathrm{Im}_{2}$ complexes at different scans rates.

All copper complexes are redox active and show cyclic voltammetric response in the potential range of $0.32-0.60 \mathrm{~V}$ which is assignable for the reduction peak of $\mathrm{Cu}(\mathrm{II}) / \mathrm{Cu}$ (I). All these complexes exhibit a quasi-reversible behavior as indicated by the non-equivalent current intensity of cathodic and anodic peaks $(\mathrm{i} / \mathrm{i}=0.512-0.322 \mathrm{~V})$. The difference $\Delta \mathrm{E}_{\mathrm{p}}=\mathrm{E}_{\mathrm{pc}}-\mathrm{E}_{\mathrm{Pa}}$ exceeds the Nernstian requirement of $59 / \mathrm{n} \mathrm{mV}(\mathrm{n}=$ number of electrons involved in reduction reaction) which suggests the quasi-reversible character of complexes. All complexes have large separation between anodic and cathodic peaks (100$250 \mathrm{mV}$ ) indicating the quasi-reversible character. The $\Delta \mathrm{E}_{\mathrm{p}}$ values of parent complexes are greater than the mixed ligand complexes.

The $\mathrm{E}_{1 / 2}$ values of present complexes are comparable with other copper complexes showing nuclease activity ${ }^{26}$. The $\mathrm{E}_{1 / 2}$ values of mixed ligand complexes are less than that of parent complexes suggesting that former complexes undergo a more facile redox change which is considered as a requirement for DNA cleavage ${ }^{27}$.
Table 5. Cyclic voltammetric data of copper(II) complexes *

\begin{tabular}{|c|c|c|c|c|c|c|}
\hline Complex & $\begin{array}{l}\text { Redox } \\
\text { couple }\end{array}$ & $\mathrm{Ep}_{\mathrm{c}} / \mathrm{V}$ & $\mathrm{Ep}_{\mathrm{a}} / \mathrm{V}$ & $\begin{array}{c}\Delta \mathrm{Ep} / \\
\mathrm{mV}\end{array}$ & $E_{1 / 2}$ & $\mathrm{I}_{\mathrm{Pa}} / \mathrm{I}_{\mathrm{Pc}}$ \\
\hline \multirow{2}{*}{ II + DNA } & \multirow{2}{*}{ II / I } & 0.34 & 0.5 & \multirow{2}{*}{250230} & 0.47 & \multirow{2}{*}{1.181 .03} \\
\hline & & 0.32 & 0.55 & & 0.44 & \\
\hline \multirow{2}{*}{ II II+DNA } & \multirow{2}{*}{ II / I } & 0.34 & 0.56 & \multirow{2}{*}{220200} & 0.45 & \multirow{2}{*}{1.151 .08} \\
\hline & & 0.32 & 0.52 & & 0.42 & \\
\hline III III & \multirow{2}{*}{ II / I } & 0.33 & 0.53 & \multirow{2}{*}{200200} & 0.43 & \multirow{2}{*}{1.121 .05} \\
\hline+ DNA & & 0.30 & 0.50 & & 0.40 & \\
\hline IV & \multirow{2}{*}{ II / I } & 0.35 & 0.59 & \multirow{2}{*}{240240} & 0.47 & \multirow{2}{*}{1.190 .92} \\
\hline IV+ DNA & & 0.33 & 0.57 & & 0.46 & \\
\hline VV & \multirow{2}{*}{ II / I } & 0.42 & 0.60 & \multirow{2}{*}{180210} & 0.51 & \multirow{2}{*}{1.131 .02} \\
\hline+ DNA & & 0.38 & 0.59 & & 0.48 & \\
\hline VI VI & \multirow{2}{*}{ II / I } & 0.34 & 0.48 & \multirow{2}{*}{140160} & 0.41 & \multirow{2}{*}{1.020 .95} \\
\hline+ DNA & & 0.28 & 0.44 & & 0.36 & \\
\hline
\end{tabular}

*Recorded in DMF at room temperature with $\mathrm{Et}_{4} \mathrm{NClO}_{4}$ as supporting electrolyte; glassy carbon as working electrode; $\mathrm{Pt}$ wire as auxiliary electrode $\mathrm{Ag} / \mathrm{AgCl}$ as reference electrode; Scan rate $50 \mathrm{mVs}^{-1}$. CT DNA - [ $\left.5 \mu \mathrm{l}\right]$

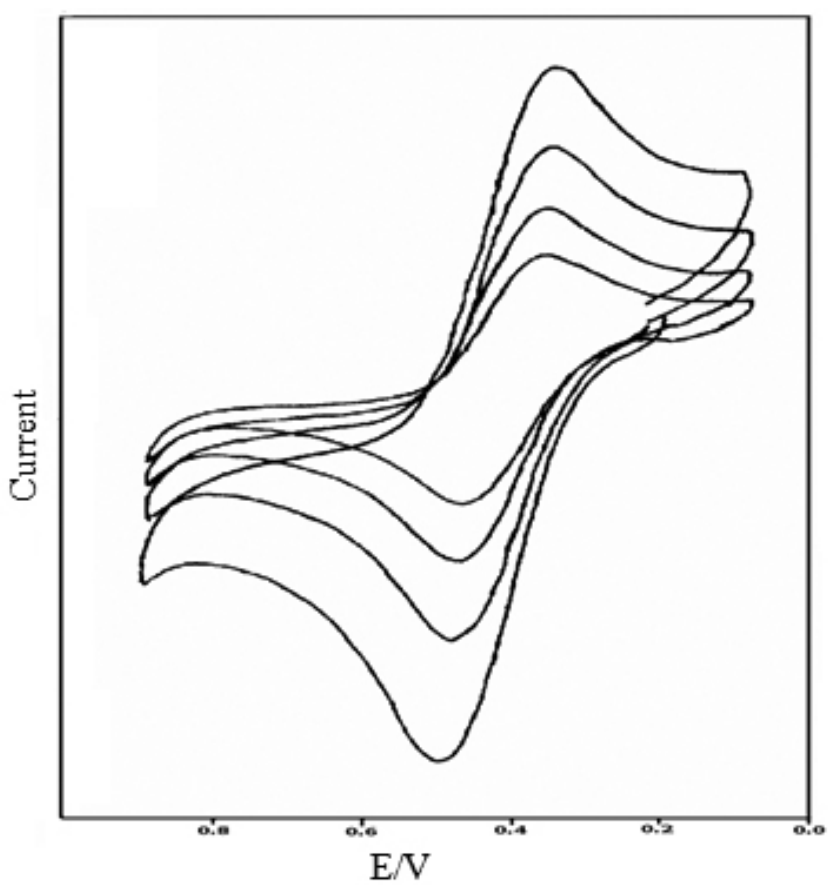

Figure 4. Cyclic voltammetry of $\left[\mathrm{Cu}(\mathrm{HAO})_{2} \mathrm{Im}_{2}\right]$, at repeated scans at different scan rates $25,50,100$ and $200 \mathrm{mVs}^{-1}$

\section{DNA Binding studies}

UV-Visible Titrations:

The interaction of copper complexes with DNA was monitored by UVVis spectroscopy (Fig. 5). The absorption spectra of copper complexes are compared with and without CT DNA. In presence of increasing amounts of CT DNA the spectra of all complexes showed hypochromicity and bathochromic shift (1-4 nm). The change in absorbance values with increasing amount of CT DNA were used to evaluate the intrinsic binding constants $\left(\mathrm{K}_{\mathrm{b}}\right)$ for all the complexes which are shown in table 6.

The higher binding constant of IV complex when compared with I is presumably due to the presence of electron donating methyl group present in the former complex. The higher binding constants of mixed ligand complexes with imidazole may be attributed to the presence of additional nitrogen donor atoms of imidazole that can interact more with DNA bases through hydrogen bonding. The higher binding constant of mixed ligands may be attributed to the $\pi$ stacking or hydrophobic interactions of excess hetero aromatic ligand. 
Table 6. Effect of CT DNA on the absorbance bands and binding constant of copper complexes and adducts.

\begin{tabular}{|c|c|c|c|c|c|}
\hline \multirow{2}{*}{ Complex } & \multicolumn{2}{|c|}{$\lambda \max / \mathrm{nm}$} & \multirow{2}{*}{$\Delta \lambda / \mathrm{nm}$} & \multirow{2}{*}{$\mathrm{H}(\%)$} & \multirow{2}{*}{$\mathrm{K}_{\mathrm{b}} / \mathrm{M}^{-1}$} \\
\hline & Free & Bound & & & \\
\hline I & 341.0 & 342.5 & 1.5 & -10.6 & $2.5 \times 10^{4}$ \\
\hline II & 339.5 & 343.5 & 4.0 & -14.1 & $3.3 \times 10^{5}$ \\
\hline III & 351.0 & 352.3 & 1.3 & -16.4 & $6.1 \times 10^{5}$ \\
\hline IV & 334.0 & 335.5 & 1.4 & -11.2 & $5.7 \times 10^{4}$ \\
\hline V & 335.0 & 337.2 & 2.2 & -14.6 & $4.8 \times 10^{5}$ \\
\hline VI & 335.5 & 336.6 & 1.1 & -16.2 & $5.9 \times 10^{5}$ \\
\hline
\end{tabular}

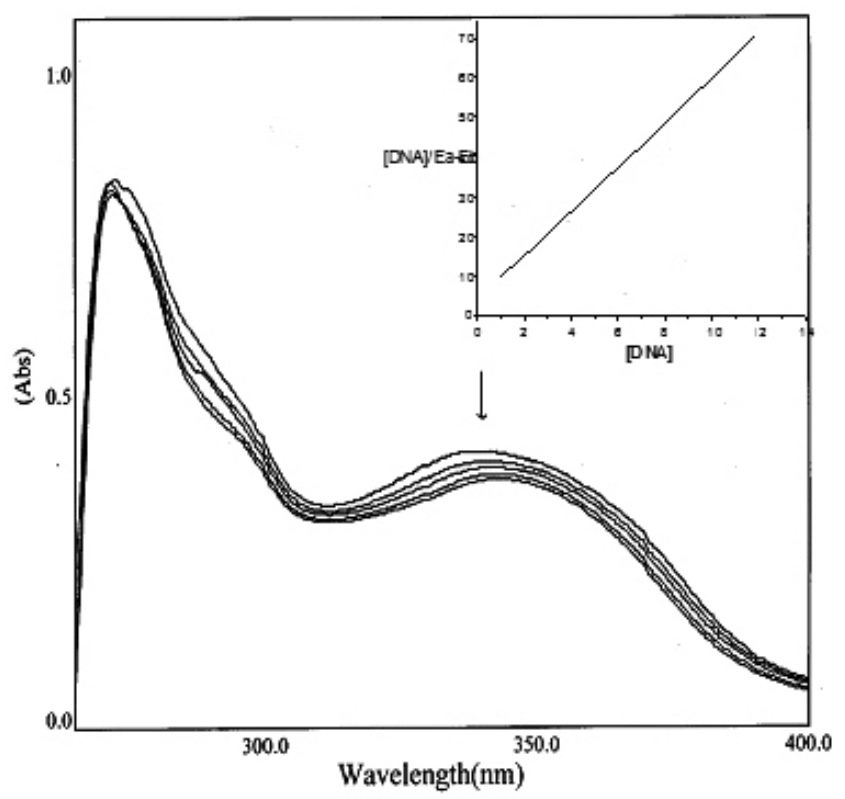

Figure 5. Absorption spectra of $\left.[\mathrm{Cu} \mathrm{SAO})_{2} \mathrm{Py}_{2}\right]$ in the absents and presences of increasing amount of DNA $[0-100 \mu \mathrm{M}]$. $[\mathrm{Cu}(\mathrm{L})]=35 \mu \mathrm{M}$. Arrow shows the decrease in absorbance upon increasing Conc. of DNA.

\section{Redox Titration:}

Binding nature of these complexes is further confirmed by redox investigation studies. Figure 6 show profile diagram of $\mathrm{Cu}(\mathrm{HAO})_{2} \mathrm{Py}_{2}$ in presence and absence of CT-DNA. On addition of CT-DNA, the complexes experience a shift in $\mathrm{E}_{1 / 2}$ values as well as $\Delta \mathrm{Ep}$ values at the scan rate of $50 \mathrm{mVs}^{-1}$. The ratio of anodic to cathodic peak currents $\mathrm{Ip}_{\mathrm{a}} / \mathrm{Ip}_{\mathrm{c}}$ in free copper complexes is decreased on addition of CT-DNA (table-5), suggesting that CTDNA moiety is bound to the complexes ${ }^{28,29}$. The change in formal potential of free copper(II) complex in the presence of DNA reveal the binding of complex with DNA . The binding constant $\mathrm{K}_{\mathrm{b}}$ and redox potential values suggest these complexes are week binders.

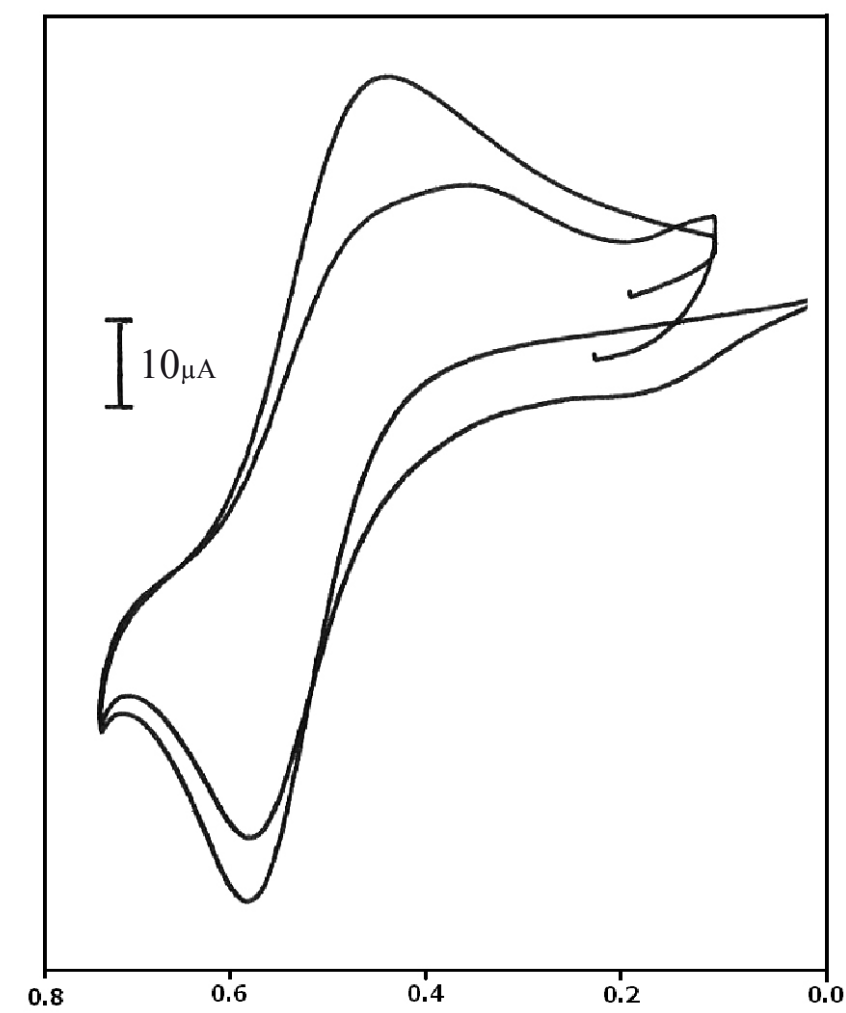

Figure 6. Cyclic Voltammograms of $1 \mathrm{mM}\left[\mathrm{Cu}(\mathrm{HAO})_{2} \mathrm{Py}_{2}\right]$ complex (a) in absence of CT DNA and (b) in presence of CT DNA $(5 \mu l)$ at scan rates.

\section{DNA Cleavage Activity}

The nuclease activity of present copper complexes has been investigated on pBR322 supercoiled plasmid DNA by agarose gel electrophoresis in the presence and in the absence of oxidant $\left(\mathrm{H}_{2} \mathrm{O}_{2}\right)$ at 120 min incubation period. The gel electrophoresis diagrams are shown in the Figure 7. The nuclease activity of all copper(II) complexes has fairly increased in presence of oxidant $\left(\mathrm{H}_{2} \mathrm{O}_{2}\right)$ (Figure 7a; all even no. lanes). $\mathrm{Cu}(\mathrm{SAO})_{2}$ complex cleaved super coiled form(SC) to nicked circular (NC) both in presence and absence of $\mathrm{H}_{2} \mathrm{O}_{2}$ which is evident from lanes $4 \& 3$ respectively. The higher cleavage activity in presence of oxidant (lane 4) is evident from Table 7. $\mathrm{Cu}(\mathrm{HAO})_{2}$ complex show complete degrading of $\mathrm{SC}$ form to $\mathrm{NC}$ and $\mathrm{OC}$ (open circular or linear form) in presence of oxidant (lane 10). In lanes $6 \& 12, \mathrm{Cu}(\mathrm{SAO})_{2} \mathrm{Py}_{2}$ and $\mathrm{Cu}(\mathrm{HAO}) \mathrm{Py}_{2}$ respectively converted $\mathrm{SC}$ form to $\mathrm{NC}$ in presence of $\mathrm{H}_{2} \mathrm{O}_{2}$. No such cleavage is observed in the absence of oxidant (lane $5 \& 11$ ). SC form has been degraded into $\mathrm{NC}$ and $\mathrm{OC}$ forms in lanes 8 \& 14 containing imidazole complexes. In the

absence of oxidant no such conversion was observed (lanes $7 \& 13$ ). From table 7 the cleavage efficiency of mixed ligand complexes are arranged in order based on cleavage efficiency (Table 7). The order is as follows:

$$
\mathrm{Cu}(\mathrm{HAO})_{2} \operatorname{Im}_{2}>\mathrm{Cu}(\mathrm{SAO})_{2} \operatorname{Im}_{2}>\mathrm{Cu}(\mathrm{HAO})_{2} \mathrm{Py}_{2}>\mathrm{Cu}(\mathrm{SAO})_{2} \mathrm{Py}_{2} \text {. }
$$

Control DNA cleavage experiment reveal the involvement of $\mathrm{OH}$ free radical as cleavage active species. In lanes $6,7 \& 8$ containing DMSO, glycerol and tert. butyl alcohol are added to reaction mixture as hydroxyl radical scavenger agents. In the presence of hydroxyl radical scavengers, especially with DMSO and tert-butyl alcohol (lanes 5 and 6), cleavage activity is diminished significantly indicating the involvement of the hydroxyl radical as active species in the cleavage process. 


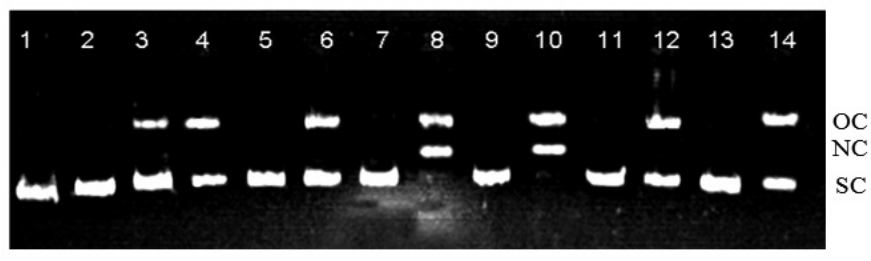

Figure7. Agarose gel (1\%) showing the results of electrophoresis of $2 \mu 1$ of $(0.10 \mu \mathrm{g} / \mathrm{ml}) \mathrm{pBR} 322$ plasmid DNA, $5 \mu 1$ of $0.1 \mathrm{M}$ Tris- $\mathrm{HCl} / \mathrm{NaCl}(\mathrm{pH} 8.0)$ buffer: $1 \mu \mathrm{l}(100 \mu \mathrm{M})$ complex in DMF; $6 \mu 1$ of sterilized water and $2 \mu 1$ of 9.0 $\mathrm{mM} \mathrm{H} \mathrm{H}_{2} \mathrm{O}_{2}$ were added, respectively, incubation at $37^{\circ} \mathrm{C}(120 \mathrm{~min})$ :

Lane 1: DNA; Lane 2: DNA + $\mathrm{H}_{2} \mathrm{O}_{2}$; Lane 3: DNA + $\mathrm{Cu}(\mathrm{SAO})_{2}$; Lane 4: DNA $+\mathrm{Cu}(\mathrm{SAO})_{2}+\mathrm{H}_{2} \mathrm{O}_{2}$; Lane 5: DNA $+\left[\mathrm{Cu}(\mathrm{SAO})_{2}\right] \mathrm{Py}_{2}$; Lane 6: DNA $+\left[\mathrm{Cu}(\mathrm{SAO})_{2}\right] \mathrm{Py}_{2}+\mathrm{H}_{2} \mathrm{O}_{2}$; Lane 7: DNA $+\left[\mathrm{Cu}(\mathrm{SAO})_{2}\right] \mathrm{Im}_{2}$; Lane 8: DNA $+\left[\mathrm{Cu}(\mathrm{SAO})_{2}\right] \mathrm{Im}_{2}+\mathrm{H}_{2} \mathrm{O}_{2}$; Lane 9: DNA $+\left[\mathrm{Cu}(\mathrm{HAO})_{2}\right]$; Lane 10: DNA + $\left[\mathrm{Cu}(\mathrm{HAO})_{2}\right]+\mathrm{H}_{2} \mathrm{O}_{2}$; Lane 11: DNA + $\left[\mathrm{Cu}(\mathrm{HAO})_{2}\right] \mathrm{Py}_{2} ;$ Lane 12: DNA + $\left[\mathrm{Cu}(\mathrm{HAO})_{2}\right] \mathrm{Py}_{2}+\mathrm{H}_{2} \mathrm{O}_{2} ;$ Lane 13: DNA $+\left[\mathrm{Cu}(\mathrm{HAO})_{2}\right] \mathrm{Im}_{2}$ and Lane 14: DNA $+\left[\mathrm{Cu}(\mathrm{HAO})_{2}\right] \mathrm{Im}_{2}+\mathrm{H}_{2} \mathrm{O}_{2}$.

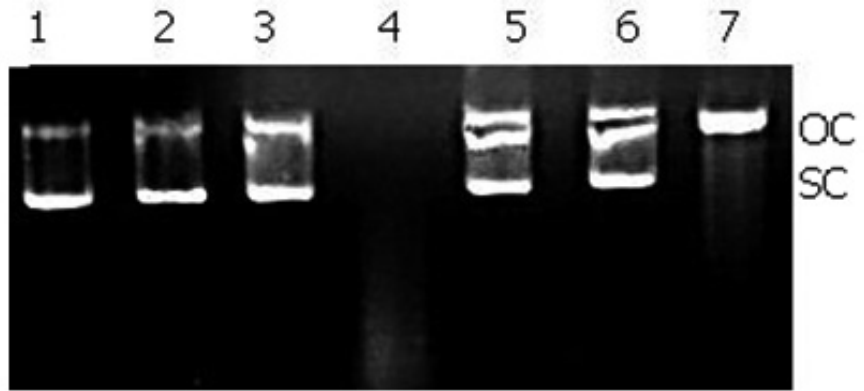

Figure 8: Agarose gel electrophoresis of pBR322 plasmid DNA ( $3.3 \mu \mathrm{l})$ treated with mixed complex $(1 \mu 1$ of $2 \mathrm{mM}), 5 \mu 1$ of $0.1 \mathrm{M}$ Tris- $\mathrm{HCl} / \mathrm{NaCl}$ buffer of $\mathrm{pH} 8.0, \mathrm{H}_{2} \mathrm{O}_{2}(24 \mathrm{mM})$ and potential inhibitors. Incubation time: $2 \mathrm{hr}\left(37^{\circ} \mathrm{C}\right)$. DMSO $(4 \mu \mathrm{L})$, tert. butyl alcohol $(2 \mathrm{M})$ and glycerol $(5 \mu \mathrm{l})$

Lane 1: DNA, Lane 2: DNA+ Cu(II) Lane 3: DNA + $\left[\mathrm{Cu}(\mathrm{SAO})_{2}\right] \mathrm{Im}_{2}$, Lane 4: DNA $+\left[\mathrm{Cu}(\mathrm{SAO})_{2}\right] \mathrm{Im}_{2}+\mathrm{H}_{2} \mathrm{O}_{2}$, Lane $5: \mathrm{DNA}+\left[\mathrm{Cu}(\mathrm{SAO})_{2}\right] \mathrm{Im}_{2}+\mathrm{DMSO}^{2}$ Lane 6: DNA $+\left[\mathrm{Cu}(\mathrm{SAO})_{2}\right] \mathrm{Im}_{2}+$ tert. butyl alcohol and Lane 7: DNA + $\left[\mathrm{Cu}(\mathrm{SAO})_{2}\right] \mathrm{Im}_{2}+$ glycerol

Table 7. DNA ( $\mathrm{pBR} 322,2 \mu \mathrm{l}$ ) cleavage data of copper complexes (For Figure. 7).

\begin{tabular}{|l|c|c|c|}
\hline Reaction condition & \% form I & \% form II & \% form III \\
\hline DNA control & 92.5 & 7.5 & -- \\
DNA+ $\mathrm{H}_{2} \mathrm{O}_{2}$ & 92.0 & 8.0 & -- \\
DNA+ I & 79.6 & 17.1 & 3.3 \\
DNA+I + $\mathrm{H}_{2} \mathrm{O}_{2}$ & 59.9 & 31.9 & 6.5 \\
DNA+ II & 84.4 & 14.6 & -- \\
DNA+ II $+\mathrm{H}_{2} \mathrm{O}_{2}$ & 57.2 & 39.8 & -- \\
DNA+ III & 78.5 & 15.2 & -- \\
DNA+ III $+\mathrm{H}_{2} \mathrm{O}_{2}$ & 28.5 & 50.5 & 2.0 \\
DNA+ IV & 75.5 & -- & 32.4 \\
DNA+ IV $+\mathrm{H}_{2} \mathrm{O}_{2}$ & 20.6 & 45.8 & -- \\
DNA+ V & 73.0 & 27.0 & -- \\
DNA+ V $+\mathrm{H}_{2} \mathrm{O}_{2}$ & 51.4 & 48.6 & -- \\
DNA+ VI & 84.1 & 25.8 & 6.8 \\
DNA+ VI $+\mathrm{H}_{2} \mathrm{O}_{2}$ & 46.3 & 41.1 & \\
\hline
\end{tabular}

\section{CONCLUSIONS}

While reports on DNA interactions of copper complexes of polypyridyl and phenanthroline ligands are numerous in the literature, those of interactions of metal oximates and, more so of mixed ligand copper complexes with oximes and aromatic bases are not investigated so far. In this study, we have attempted to unravel the DNA interactions and nuclease activity of mixed ligand copper complexes. The reduction in peak intensity (absorption spectra) is in analogy with similar observation made earlier for other mixed ligand complexes ${ }^{30,31}$. Since the binding constants values are appreciable and less than $10^{6} \mathrm{M}^{-1}$ and since the complexes contain aromatic hydrophobic groups these complexes may be better regarded as partial intercalators of DNA. Nuclease activity of imidazole complexes is more than the corresponding pyridine complexes. The mixed ligand complexes of imidazole are found to be better DNA binding agents and efficient nucleases than the corresponding pyridine complexes possibly due to the additional nitrogen atom that may facilitate to strengthen DNA interaction via hydrogen bonding with DNA bases.

The present studies revealed that the copper complexes show insignificant nuclease activity in the absence of oxidant. However the activity is greatly enhanced in the presence of oxidant facilitated by the production of hydroxyl free radicals which can damage DNA via oxidative path. Insignificant nuclease activity of complexes in the absence of oxidant is presumably due to the more stability of complexes attributed to their trans structure.

\section{ACKNOWLEDGMENT}

The authors thank University Grant Commission [F12-118/2001], New Delhi, India for financial support.

\section{REFERENCES}

1. A.Yan, L. Si-Dong, D. Shu-Yi, J. Liang-Nian, M. Zong-Wan, J. Inorg. Biochem., 100, 1586, (2006).

2. Y. Z. Cheng, Z. Jing, B. W.Yan, X. Y. Cai, and Y. Pin; J. Inorg. Biochem.,101, 10, (2007).

3. A. R. Chakravarty, J. Chem. Sci., 118, 443, (2006)

4. S. Dhar and A. R. Chakravarty, Inorg. Chem., 44, 2582, (2005)

5. A. Sreedhara and J. A.Cowan, Chem. Commun., 1737, (1998)

6. R. Cejudo, G. Alzuet, M. G. Alvarez, J. G. Gimenez, J. Borras and M. L. Gonzalez, J. Inorg. Biochem., 100, 70, (2006)

7. V. Uma, M. Kanthimathi, T. Weyhermuller and U. N. Balachandran, $J$. Inorg. Biochem., 99, 2299, (2005).

8. Y. An, M. L. Tong, L. N. Ji and Z. W. Mao, Dalton Trans., 2066, (2006)

9. K. Dhara, J. Ratha, M. Manassero, X. Wang, S. Gao and P. Banerjee, J. Inorg. Biochem., 101, 95, (2007)

10. J. K. B. Leigh, and M. Z. Jeffrey, Curr. Opin. Chem. Biol., 9, 135, (2005)

11. M. A. Akbar and S. F. Livingstone, Coord. Chem. Rev., 13, 101, (1974)

12. A. Chakravorthy, Cord. Chem. Rev., 13, 1, (1974)

13. P. S. Reddy and K. H. Reddy, Polyhedron, 19, 168, (2000).

14. D. Mandal and B. D. Guptha, Organometallics, 24, 1501, (2005)

15. M. S. Surendra Babu, K. H. Reddy and P. G. Krishna, Polyhedron, 26, $572,(2007)$

16. K. H. Reddy, M. S. Surendra Babu, P. S. Babu and S. Dayananda, Ind. J Chem. Sect.A., 43, 1233, (2004).

17. M. E. Reichmann, S.A.Rice, C. A. Thomas and P. Doty, J. Am. Chem. Soc., 76, 3047, (1954).

18. A. Wolfe, G. H. Shimer and T. Meehan, Biochemistry., 26, 6392, (1987).

19. C. R. K. Rao and P. S. Zacharias, Polyhedron, 16, 1201, (1997).

20. D. Cupertino, M. McPartline and A. M. Zissimos, Polyhedron, 20, 3239, (2001).

21. A. Jaggi, S. Chandra and K. K. Sharma, Polyhedron, 4, 163, (1985).

22. K. Nakamoto, Infrared Spectra of Inorganic and coordination Compounds $\left(2^{\text {nd }}\right.$ ed. Wiley-Interscience New York) 1970.

23. A. L. Sharma, I. O. Singh, M. A. Singh, H. R. Singh, R. M. Kadam, M. K. Bhide and M. D. Sastry, Trans. Met. Chem., 26, 532, (2001).

24. B. J. Hathaway, Struct. Bond., 14, 60, (1973).

25. M. Massacesi, D. G. Ponticelli, A. V. Budha and V. Krishnan, J. Mol Struct., 48, 55, (1978)

26. K. H. Reddy, P. S. Reddy and P. R. Babu, J. Inorg. Biochem., 7, 169, (1999).

27. A. A. Kumbhar, S. B. Rendye, D. X. West and A. E. Libetra, Trans. Met. Chem., 16, 276, (1991).

28. J. Annaraj, S. Srinivasan, K. M. Ponvel and P. Athappan, J. Inorg. Biochem., 99 669, (2005).

29. S. Parveen and F. Arjmand, Indian J. Chem. Sect., 44A, 1151, (2005).

30. C. C. Cheng, S. E. Rokita and C. J. Burrows, Angew Chem. Int Ed. Engl., 32, $273,(1993)$

31. Y. Wang, N. Okabe and M. Odoko, Chem. Pharm. Bull., 53, 91, (2005). 